\title{
The reactions of 4-chloro-2-butanol and 3-chloro-1-butanol with aqueous sodium hydroxide, and 1-chloro-2-propanol and 2-chloro-1- propanol with isopropyl amine
}

\author{
Kalevi Pihlaja,* Kari Aaljoki, Maija-Riitta Lyytinen, \\ Marja-Liisa Huusko, and Marjut Hotokka \\ Department of Chemistry, University of Turku, FI-20014 Turku, Finland \\ E-mail: kpihlaja@utu.fi
}

Dedicated to Professor William Bailey on the occasion of his $65^{\text {th }}$ birthday

\begin{abstract}
The total reaction of 4-chloro-2-butanol 1 with $\mathrm{NaOH}(\mathrm{aq})$ is dominated (74\%) by intramolecular substitution $\left(\mathrm{S}_{\mathrm{N}} \mathrm{i}\right)$, besides which bimolecular substitution $\left(\mathrm{S}_{\mathrm{N}} 2,12 \%\right)$ and 1,4-elimination (i.e. fragmentation, contrary to earlier arguments) exhibit a significant contribution (11\%). The total reaction of 3-chloro-1-butanol 2 instead is dominated by 1,4- (72\%) and 1,2-elimination (25\%), the substitution reactions being just observable $\left(\mathrm{S}_{\mathrm{N}} \mathrm{i} 2 \%\right.$ and $\left.\mathrm{S}_{\mathrm{N}} 21 \%\right)$. In 1 both the $+\mathrm{I}$-effect and the conformational factors in the intermediate $\gamma$-chloroalkoxy anion favour the $\mathrm{S}_{\mathrm{N}} \mathrm{i}$-reaction, whereas in 2 the situation is opposite and the location of $\mathrm{Cl}$ on a secondary carbon also makes the $\mathrm{S}_{\mathrm{N}}$ i-reaction less favourable. The relative proportions of 1,4- and 1,2-eliminations for 2 can be explained by thermodynamic basis since the consequent products are more stable than the corresponding products from 1. 1-chloro-2-propanol 3 and 2-chloro-1-propanol 4 both react with isopropyl amine giving the same product, namely 1-isopropylamino-2-propanol, which indicates that the reaction proceeds through the propylene oxide intermediate. Compound $\mathbf{1}$ also reacted with isopropyl amine predominantly via $\mathrm{S}_{\mathrm{N}}$ i-reaction, giving first 2-methyloxetane which then further gave 4isopropylamino-2-butanol, whereas 2 gave 3-isopropylamino-1-butanol through a direct $\mathrm{S}_{\mathrm{N}} 2$ reaction.
\end{abstract}

Keywords: 1,2- and 1,3-Chlorohydrins, reactions in alkali, kinetics, mechanisms

\section{Introduction}

In alkaline media 1,3-halohydrins can decompose in the following ways: $:^{1-3}$

(1) intramolecular substitution $\left(\mathrm{S}_{\mathrm{N}} \mathrm{i}\right)$ leading to the formation of an oxetane; 
(2) 1,4-elimination (fragmentation) which leads to an alkene and an oxo compound in the consequent cleavage;

(3) 1,2-elimination leading to an $\alpha, \beta$ - or a $\beta, \gamma$-unsaturated alcohol;

(4) bimolecular substitution $\left(\mathrm{S}_{\mathrm{N}} 2\right)$ leading to a 1,3-diol.

With isopropyl amine the reaction appears to proceed according to routes (1) or (4). ${ }^{4}$

The type of reaction depends on the structure of the substrate and the reaction conditions. ${ }^{1 \mathrm{a}, 2}$ Decomposition can take place simultaneously by more than one of the above four routes. In the present case the first alternative is the most interesting: ${ }^{1,2}$ According to Bartók et al. ${ }^{1}$ and Searles et $a .^{2}$ in the first step a $\gamma$-chloroalkoxy anion is formed and then the chlorine is replaced by the oxygen atom and an oxetane is formed (route 1). Alternatively, the $\gamma$-chloroalkoxy anion can release the halogen and split into an alkene and oxo compound via 1,4-elimination (route 2).

Only a limited number of studies on the alkaline dehydrochlorination of 1,3-chlorohydrins have been made in rather variable conditions. Bartók and coworkers ${ }^{1}$ studied the reactions of several $2-^{1 \mathrm{~b}}$ and 2,2-disubstituted ${ }^{1 \mathrm{c}}$ and 1 - $^{1 \mathrm{~d}}$ and 1,1-disubstituted 3-chloro-1-propanols ${ }^{1 \mathrm{e}}$ in aqueous 1,4-dioxane (3:7) using $\mathrm{Ba}(\mathrm{OH})_{2}$ as a base. They were obliged to use very high temperatures (even as high as $125^{\circ} \mathrm{C}$ ). Usually it is recommended that one should follow the studied reactions up till 3 half-lives. However, Bartók et al. ${ }^{1}$ stopped even after less than 20-30\% conversion.

Bartók et al. ${ }^{1}$ concluded that the predominant reaction route was (1), based on reaction product analyses. However, 1-chloro-3-propanol, 3-chloro-1-phenyl-propanol and 3-chloro-2-phenyl-1propanol exhibited a variable amount of 1,2-elimination $(30,80$ and $70-80 \%$, respectively). The $-\mathrm{I}-$ effect and mesomerism of the phenyl group increase the stability of such a conformation which favours 1,2-elimination and splitting.

Searles et $a .^{2}{ }^{2}$ were mainly interested in the syntheses of oxetanes which they tried to prepare by treating several 2- or 2,2-disubstituted 3-bromo-1-propanols with 15 or 50\% aqueous $\mathrm{KOH}$. They state that at either base concentrations, substituents at carbon 2 favour the 1,4-elimination process (fragmentation) over intramolecular substitution. However, their own results prove the opposite, i.e. in $50 \%$ aqueous $\mathrm{KOH}$ the latter reaction was favoured over the former by a factor of 1.7-8. Similarly, Gaylord et al. ${ }^{5}$ tried to prepare oxetanes by treating 2-chloro-4-hexanol and 1-phenyl-3chloro-1-butanol with powdered $\mathrm{KOH}$. In the former case they obtained 25\% of 2-ethyl-4methyloxetane but in the latter none.

Richardson et al. ${ }^{3}$ studied the basic decomposition of 3-chloro-1-propanol and its 2,2-dimethyl derivative as well as that of 4-chloro-2-methyl-1-butanol in $40 \%$ aqueous methanol. It is not easy to understand how their work was really done since in their kinetic experiments the initial substrate to $\mathrm{NaOH}$ ratio varied from 2.4 to 11 . In other words all of base was consumed after the reaction had proceeded even less than $10 \%$. When determining the products the substrate to base ratio was 0.5 , 11 and 0.6, respectively. In the case of 3-chloro-1-propanol and 4-chloro-2-methyl-1-butanol they determined the \% yields of different products after 28 and 39\% conversion but for 2,2-dimethyl-3chloro-1-propanol after 10-20 half-lives. In fact in the latter case the outcome would have been the same after ca $10 \%$ conversion since all base was then already consumed. 


\section{Results and Discussion}

\section{Reactions of 4-chloro-2- (1) and 3-chloro-1-butanols (2) with aqueous $\mathrm{NaOH}$}

The reactions of 1 and 2 were carried out in water at four different base concentrations $(0.1,0.2,0.4$ and $1.00 \mathrm{M} \mathrm{NaOH}$ ). The base concentration had no systematic effect on the second-order rate coefficients obtained (Table 1). According to Richardson et al. ${ }^{3}$ temperature had no remarkable effect on the product ratios either. For determining the activation parameters the reactions were carried out in $0.1 \mathrm{M} \mathrm{NaOH}(\mathrm{aq})$ each at 6 different temperatures (Table 2). The activation parameters $\left(\mathrm{E}_{\mathrm{a}}, \mathrm{A}, \Delta \mathrm{H}^{\#}\right.$ and $\Delta \mathrm{S}^{\#}$; Table 3 ) were calculated according to the normal procedure. The rate constants determined by Bartók and Bozóki-Bartók ${ }^{1 \mathrm{e}}$ at $80^{\circ} \mathrm{C}$ for 1 and by Forsberg ${ }^{6}$ at $80.07{ }^{\circ} \mathrm{C}$ for 1 and 2 are relatively close to those determined in this work (Table 2). However, the activation parameters determined by the former authors are far different from those in this work (Table 4) probably due to the different solvent and relatively mild base. Forsberg, ${ }^{6}$ however, determined the decomposition rates for $\mathbf{1}$ and 2 only at $80.07{ }^{\circ} \mathrm{C}$.

Table 1. The values of second order rate constants for 4-chloro-2-butanol 1 and 3-chloro-1-butanol 2 at various $\mathrm{NaOH}$ concentrations (b)

\begin{tabular}{ccc}
\hline $\mathrm{b}, \mathrm{mol} \mathrm{dm}$ & $\mathbf{1}, 60.2{ }^{\circ} \mathrm{C}, 10^{5} \mathrm{k}_{\mathrm{r}} \mathrm{dm}^{3} \mathrm{~mol}^{-1} \mathrm{~s}^{-1}$ & $\mathbf{2 , 5 0 . 0}{ }^{\circ} \mathrm{C}, 10^{4} \mathrm{k}_{\mathrm{r}} \mathrm{dm}^{3} \mathrm{~mol}^{-1} \mathrm{~s}^{-1}$ \\
\hline 0.100 & $9.77 \pm 0.12$ & $3.25 \pm 0.04$ \\
0.200 & $9.89 \pm 0.04$ & $2.90 \pm 0.13$ \\
0.400 & $11.8 \pm 0.04$ & $3.23 \pm 0.05$ \\
1.000 & $10.8 \pm 1.0$ & $3.35 \pm 0.26$ \\
Average & $10.8 \pm 1.0$ & $3.16 \pm 0.16$ \\
\hline
\end{tabular}

Table 2. The values of second order rate constants for 4-chloro-2-butanol 1 and 3-chloro-1-butanol 2 at $0.100 \mathrm{~mol} \mathrm{dm}{ }^{-3} \mathrm{NaOH}$ concentration at various temperatures

\begin{tabular}{ccc}
\hline Temperature, ${ }^{\circ} \mathrm{C}$ & $\mathbf{1}, 10^{5} \mathrm{k}_{\mathrm{r}} \mathrm{dm}^{-3} \mathrm{~mol}^{-1} \mathrm{~s}^{-1}$ & $\mathbf{2 , 1} \mathbf{1}^{4} \mathrm{k}_{\mathrm{r}} \mathrm{dm}^{3} \mathrm{~mol}^{-1} \mathrm{~s}^{-1}$ \\
\hline 40.0 & - & $1.05 \pm 0.03$ \\
45.0 & -- & $1.91 \pm 0.07$ \\
50.0 & $2.63 \pm 0.19$ & $3.25 \pm 0.04$ \\
55.0 & $5.78 \pm 0.20$ & $5.40 \pm 0.30$ \\
60.0 & - & $9.80 \pm 0.12$ \\
60.2 & $9.77 \pm 0.10^{\mathrm{a}}$ & - \\
65.0 & $15.2 \pm 0.9$ & - \\
70.0 & $27.0 \pm 0.4$ & $25.2 \pm 0.7$ \\
79.7 & $71.3 \pm 1.0^{\mathrm{b}, \mathrm{c}}$ & $-{ }^{\mathrm{d}}$ \\
\hline
\end{tabular}

${ }^{a}$ With external standard; all the other cases with internal standard.

${ }^{b} 85.0$ at $80{ }^{\circ} \mathrm{C}^{1 \mathrm{~d} \mathrm{c}} 82$ and ${ }^{\mathrm{d}} 75$ at $80.07^{\circ} \mathrm{C} .{ }^{4}$ 
The decomposition of $\mathbf{1}$ was predominated by the $\mathrm{S}_{\mathrm{N}} \mathrm{i}$ reaction leading to 2-methyloxetane (Scheme 1 and Table 3) which can be explained by the most favoured conformation of the $\gamma$ chloroalkoxy anion in this case (A, Scheme 2). Opposite to the statements of Richardson et al. ${ }^{3}$ and Forsberg $^{6}$ that 1,4-elimination can occur only if a substituted alkene is formed, $\mathbf{1}$ clearly gave ethene (+acetaldehyde, Tables 3 and 4). 2 gave only very small amount of 2 -methyloxetane $\left(\mathrm{S}_{\mathrm{N}} \mathrm{i}\right)$, the main products being 1-propene ( $+\mathrm{CH}_{2}=\mathrm{O}, 1,4-\mathrm{E} /$ fragmentation) and 2-buten-1-ol blanco (1,2-E) besides a small amount of butane-1,3-diol $\left(\mathrm{S}_{\mathrm{N}} 2\right.$, Tables 3 and 4) which is again in agreement with its favoured conformation (B, Scheme 2). In general, it can be mentioned that the product analyses have usually been far from complete. The few more comprehensive examples are collected in Table 4. For instance, Bartók and coworkers ${ }^{1}$ were also mostly interested in oxetane formation although in some cases they tried to explain also the presence of other products.

Table 3. Kinetic parameters for the total $(\mathbf{T})$ and the partial reactions $\left(\mathbf{S}_{\mathbf{N}} \mathbf{i}, \mathbf{1 , 4 - E}\right.$, and $\left.\mathbf{1 , 2}-\mathbf{E}\right)$ in $0.100 \mathrm{~N} \mathrm{NaOH}(\mathrm{aq})$ and the average distribution of final reaction products at various base concentrations for 4-chloro-2-butanol 1 and 3-chloro-1-butanol 2

\begin{tabular}{|c|c|c|}
\hline & 1 & 2 \\
\hline $\mathbf{T}: \mathrm{A}, \mathrm{dm}^{3} \mathrm{~mol}^{-1} \mathrm{~s}^{-1}$ & $12.2 \times 10^{11}\left(1.7 \times 10^{10}\right)^{a}$ & $7.0 \times 10^{11}$ \\
\hline $\mathbf{T}: \mathrm{E}_{\mathrm{a}}, \mathrm{kJmol}^{-1}$ & $102.9 \pm 3.2(89.6 \pm 3.3)^{\mathrm{a}}$ & $94.9 \pm 1.2$ \\
\hline $\mathbf{T}: \Delta \mathrm{H}^{\#}, \mathrm{kJmol}^{-1}$ & $100.1 \pm 3.2(86.6 \pm 3.4)^{\mathrm{a}}$ & $92.2 \pm 1.1$ \\
\hline $\mathbf{T}: \Delta \mathrm{S}^{\#}, \mathrm{Jmol}^{-1} \mathrm{~K}^{-1}$ & $-22.9 \pm 9.5(-58.9 \pm 9.2)^{\mathrm{a}}$ & $-27.3 \pm 3.6$ \\
\hline $\mathbf{S}_{\mathbf{N}} \mathbf{i}: \mathrm{A}, \mathrm{dm}^{3} \mathrm{~mol}^{-1} \mathrm{~s}^{-1}$ & $7.5 \times 10^{11}$ & \\
\hline $\mathbf{S}_{\mathbf{N}} \mathbf{i}: \mathrm{E}_{\mathrm{a}}, \mathrm{kJmol}^{-1}$ & $102 \pm 3$ & \\
\hline $\mathbf{S}_{\mathbf{N}} \mathbf{i}: \Delta \mathrm{H}^{\#}, \mathrm{kJmol}^{-1}$ & $100 \pm 3$ & \\
\hline $\mathbf{S}_{\mathbf{N}} \mathbf{i}: \Delta \mathrm{S}^{\#}, \mathrm{Jmol}^{-1} \mathrm{~K}^{-1}$ & $-27 \pm 8$ & \\
\hline 1,4-E: $\mathrm{A}, \mathrm{dm}^{3} \mathrm{~mol}^{-1} \mathrm{~s}^{-1}$ & $2.3 \times 10^{11}$ & $6.8 \times 10^{10}$ \\
\hline 1,4-E: $\mathrm{E}_{\mathrm{a}}, \mathrm{kJmol}^{-1}$ & $104 \pm 4$ & $96 \pm 1$ \\
\hline 1,4-E: $\Delta \mathrm{H}^{\#}, \mathrm{kJmol}^{-1}$ & $100 \pm 2$ & $91 \pm 2$ \\
\hline 1,4-E: $\Delta \mathrm{S}^{\#}, \mathrm{Jmol}^{-1} \mathrm{~K}^{-1}$ & $-41 \pm 6$ & $-53 \pm 6$ \\
\hline 1,2-E: $\mathrm{A}, \mathrm{dm}^{3} \mathrm{~mol}^{-1} \mathrm{~s}^{-1}$ & $1.5 \times 10^{11}$ & $1.7 \times 10^{10}$ \\
\hline 1,2-E: $\mathrm{E}_{\mathrm{a}}, \mathrm{kJmol}^{-1}$ & $102 \pm 2$ & $95 \pm 1$ \\
\hline 1,2-E: $\Delta \mathrm{H}^{\#}, \mathrm{kJmol}^{-1}$ & $99 \pm 2$ & $94 \pm 1$ \\
\hline 1,2-E: $\Delta \mathrm{S}^{\#}, \mathrm{Jmol}^{-1} \mathrm{~K}^{-1}$ & $-47 \pm 5$ & $-34.1 \pm 4$ \\
\hline Temperature & $60.2^{\circ} \mathrm{C}$ & $50.0^{\circ} \mathrm{C}$ \\
\hline $\mathrm{S}_{\mathrm{N}} \mathrm{i}$-reaction $(\%)$ & 2-Methyloxetane (74) & 2-Methyloxetane (1) \\
\hline 1,4-elimination $(\%)$ & Ethene $+\mathrm{CH}_{3} \mathrm{CHO}(11)$ & 1-Propene $+\mathrm{CH}_{2}=\mathrm{O}(71.5)$ \\
\hline 1.2-elimination $(\%)$ & - & 2-Buten-1-ol (25.5) \\
\hline $\mathrm{S}_{\mathrm{N}} 2$-reaction $(\%)$ & Butane-1,3-diol (15) & Butane-1,3-diol (2) \\
\hline
\end{tabular}

${ }^{\mathrm{a}}$ Recalculated from the rate constants by Bartók et al. ${ }^{1 \mathrm{e}}$ in $0.015 \mathrm{~N} \mathrm{Ba}(\mathrm{OH})_{2}$ solution $\left(\mathrm{b} / \mathrm{c}_{\mathrm{o}}=1.46\right)$. 
Table 4. Product analyses (\%)

\begin{tabular}{|c|c|c|c|c|}
\hline 1,3-Chlorohydrins & \multicolumn{4}{|c|}{ Products } \\
\hline \multirow{2}{*}{$\begin{array}{c}\mathrm{HOCH}_{2} \mathrm{CH}_{2} \mathrm{CH}_{2} \mathrm{Cl} \\
\left(100^{\circ} \mathrm{C}\right)^{3}\end{array}$} & Oxetane & $\begin{array}{l}\text { 2-Propen-1- } \\
\quad \text { ol }\end{array}$ & $\begin{array}{l}\text { 3-Methoxy- } \\
\text { 1-propanol }\end{array}$ & $\begin{array}{l}\text { Butane-1,3- } \\
\quad \text { diol }\end{array}$ \\
\hline & 15 & 5 & 53 & 28 \\
\hline \multirow[t]{2}{*}{$\begin{array}{c}\left(\mathrm{CH}_{3}\right)_{2} \mathrm{C}(\mathrm{OH}) \mathrm{CH}_{2} \mathrm{CH}_{2} \mathrm{Cl} \\
\left(100^{\circ} \mathrm{C}\right)^{3}\end{array}$} & 2,2-Dimethyloxetane & $\begin{array}{l}\text { 2-Methyl-3- } \\
\text { buten-2-ol }\end{array}$ & $\begin{array}{c}\text { 4-Methoxy- } \\
\text { 2-methyl-2- } \\
\text { butanol }\end{array}$ & \\
\hline & 82 & 2 & 16 & \\
\hline \multirow{2}{*}{$\begin{array}{c}\mathrm{HOCH}_{2} \mathrm{CHC}_{6} \mathrm{H}_{5} \mathrm{CH}_{2} \mathrm{Cl} \\
\left(100^{\circ} \mathrm{C}\right)^{1 \mathrm{~b}}\end{array}$} & 2-Phenyloxetane & $\begin{array}{l}\text { 2-Phenyl-2- } \\
\text { propen-1-ol }\end{array}$ & & \\
\hline & $20-30$ & $70-80$ & & \\
\hline \multirow{2}{*}{$\begin{array}{c}\mathrm{HOCH}_{2} \mathrm{C}\left(\mathrm{CH}_{3}\right)_{2} \mathrm{CH}_{2} \mathrm{Cl} \\
\left(85^{\circ} \mathrm{C}\right)^{3}\end{array}$} & 3,3-Dimethyloxetane & $\begin{array}{l}\text { 2-Methyl-1- } \\
\text { propene }\end{array}$ & & \\
\hline & 46 & 54 & & \\
\hline \multirow{2}{*}{$\begin{array}{c}\mathrm{CH}_{3} \mathrm{CHOHCH}_{2} \mathrm{CHClCH}_{2} \\
\mathrm{CH}_{3}\left(75-100^{\circ} \mathrm{C}\right)^{5}\end{array}$} & $\begin{array}{l}\text { 2-Ethyl-4- } \\
\text { methyloxetane }\end{array}$ & 4-Hexen-3-ol & 1-propene & $\begin{array}{l}\text { Propanoic } \\
\text { acid }\end{array}$ \\
\hline & 25 & 25 & 21 & 18 \\
\hline \multirow{2}{*}{$\begin{array}{c}\mathrm{CH}_{3} \mathrm{CHOHCH}_{2} \mathrm{CH}_{2} \mathrm{Cl} 1 \\
\left(60^{\circ} \mathrm{C}\right)\end{array}$} & 2-Methyloxetane & & $\begin{array}{c}\text { Ethene }+ \\
\text { Ethanal }\end{array}$ & $\begin{array}{l}\text { Butane-1,3- } \\
\quad \text { diol }\end{array}$ \\
\hline & 74 & & 11 & 15 \\
\hline \multirow{2}{*}{$\begin{array}{c}\mathrm{HOCH}_{2} \mathrm{CH}_{2} \mathrm{CHClCH}_{3} 2 \\
\left(50{ }^{\circ} \mathrm{C}\right)\end{array}$} & 2-Methyloxetane & 2-Buten-1-ol & $\begin{array}{l}\text { 1-Propene + } \\
\text { Methanal }\end{array}$ & $\begin{array}{l}\text { Butane-1,3- } \\
\quad \text { diol }\end{array}$ \\
\hline & 1 & 25.5 & 71.5 & 2 \\
\hline
\end{tabular}

The reactions of 1,3-chlorohydrins with base fall into the category of parallel second-order reactions ${ }^{3}$, where the overall rate coefficient $\left(\mathrm{k}_{\mathrm{r}}\right)$ equals the sum $\left(\Sigma \mathrm{k}_{\mathrm{i}}\right)$ of the second-order rate coefficients for the $\mathrm{S}_{\mathrm{N}} \mathrm{i}, 1,4-\mathrm{E}$ (fragmentation), $\mathrm{S}_{\mathrm{N}} 2$ and 1,2-E reactions, i.e.

$$
\mathrm{k}_{\mathrm{i}}=\mathrm{k}_{\mathrm{r}}(\% \text { yield of } \mathrm{i} / 100) .
$$

Taking this into account together with the fact that according to Richardson et al. ${ }^{3}$ the percentage yield of various products does not seem to depend much on temperature we were able to evaluate the approximate activation parameters for the partial main reactions of $\mathbf{1}$ and $\mathbf{2}$ (Table 3 ). 


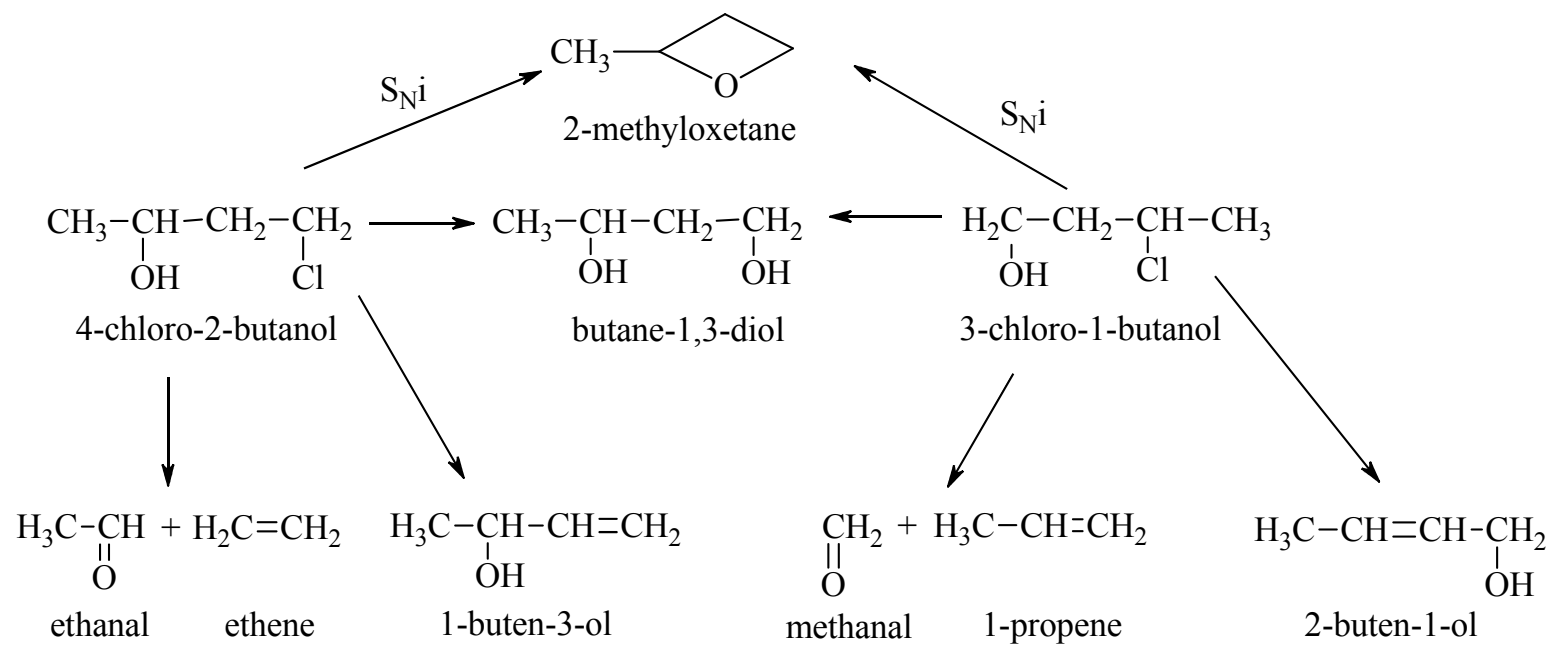

Scheme 1. Different routes for alkaline dehydrochlorination of $\mathbf{1}$ and 2.

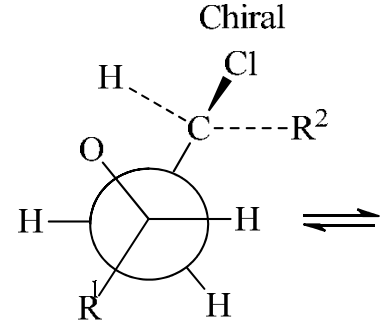

A

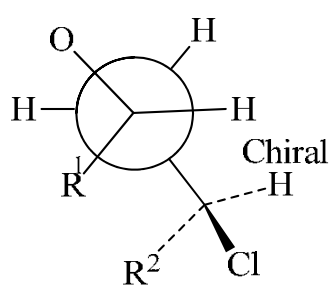

B

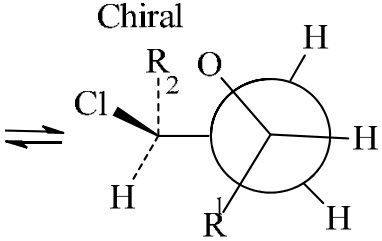

$\mathrm{C}$

Scheme 2. Conformational illustration of $\gamma$-chloroalkoxy anion, $1 \mathrm{R}^{1}=\mathrm{CH}_{3}, \mathrm{R}^{2}=\mathrm{H} ; \mathbf{2} \mathrm{R}^{1}=\mathrm{H}, \mathrm{R}^{2}=$ $\mathrm{CH}_{3}$.

When inspecting the activation parameters shown in Table 3 it appears that the faster dehydrochlorination of 2 is mainly due to the $8 \mathrm{~kJ} \mathrm{~mol}^{-1}$ lower activation enthalpy. The activation parameters $\left(\mathrm{E}_{\mathrm{a}}\right.$ and $\left.\Delta \mathrm{H}^{\#}\right)$ for the partial reactions (Table 3) of $\mathbf{1}$ or $\mathbf{2}$ do not differ very much from those for the total reaction except the A and entropy terms. When comparing our activation parameters $\left(\mathrm{E}_{\mathrm{a}}, \Delta \mathrm{H}^{\#}\right.$ and $\left.\Delta \mathrm{S}^{\#}\right)$ for the partial reactions of $\mathbf{1}$ they are very close to those determined by Richardson et al. ${ }^{3}$ for the same type of partial reactions of 3-chloro-1-propanol and 4-chloro-2methyl-2-butanol despite the fact that the latter reactions were carried out in $40 \%$ aqueous methanol.

As to the reactions of chlorohydrins in mere water or in acid solution it has been shown especially with 1,2-chlorohydrins that practically no reaction occurs or at least they are extremely slow. ${ }^{7}$ 


\section{Reactions of 1-chloro-2- (3) and 2-chloro-1-propanols (4) with isopropylamine}

In a course of studies related to licence arguments concerning the synthesis of propranolol we showed that the reaction of 1-chloro-3-(1-naphthoxy)-2-propanol 5 gave 1-isopropylamino-3-(1naphthoxy)-2-propanol 6 (propranolol) with a rate $1.22 \times 10^{-5} \mathrm{~s}^{-1}$ in isopropyl amine whereas that of 1,2-epoxy-3-(1-naphthoxy)-2-propane 7 gave the same product with 10 -fold rate, $1.22 \times 10^{-4} \mathrm{~s}^{-1}$ both at $60{ }^{\circ} \mathrm{C} .{ }^{8}$ The epoxide formation in the reaction of 5 could be verified with thin layer chromatography using a 35:10:1 $\mathrm{C}_{6} \mathrm{H}_{6}+\mathrm{CH}_{3} \mathrm{OH}+\mathrm{CH}_{3} \mathrm{COOH}$ eluent. When this reaction was followed gas chromatographically (SE-30 column, $\mathrm{t}=170^{\circ} \mathrm{C}$ ) it was found that some epoxide was still present after several half-lives as compared to the reaction of 7 . This is an indication that epoxide is an intermediate (rate determining step in case of 5) which reached a so-called steadystate making its observation a bit less easy.

Both the reaction of 1-chloro-2-propanol 3 and that of 2-chloro-1-propanol 4 with isopropyl amine gave principally the same product, namely 1-isopropylamino-2-propanol $\mathbf{8}$ the rate ratio being $7: 1,{ }^{9}$ the first-order rate coefficients being $(9.8 \pm 0.7) \times 10^{-6}$ and $(1.3 \pm 0.1) \times 10^{-6}$ for 3 and $\mathbf{4}$, respectively. Since the reaction of propylene oxide with isopropyl amine ${ }^{6,8}$ gave the same end product we could conclude that the reaction of $\mathbf{3}$ and $\mathbf{4}$ first gives the epoxide with $\mathrm{S}_{\mathrm{N}} \mathrm{i}$-mechanism, which then reacts further with another molecule of isopropyl amine with $\mathrm{S}_{\mathrm{N}} 2$-mechanism leading to compound $\mathbf{8}$ in agreement with the results mentioned above. Literature results indicate that even conformational factors favour the reaction proceeding via the epoxide. ${ }^{4,10}$

\section{Reactions of 4-chloro-2- (1) and 3-chloro-1-butanols (2) with isopropylamine}

In relation to the reactions of chlorides 1 and 2 with $\mathrm{NaOH}(\mathrm{aq})$ it was also interesting to study their reactions with isopropyl amine since based on their reactions with $\mathrm{NaOH}(\mathrm{aq})$ one could expect that they would give different products as indeed was the case (see experimental). As to 1 the reaction can proceed first with $\mathrm{S}_{\mathrm{N}} \mathrm{i}$-mechanism leading to 2-methyloxetane which reacts then with another molecule of isopropylamine leading to the product. ${ }^{9 a}$ Alternatively $\mathbf{1}$ can react directly to 4isopropylamino-2-butanol 9 by $\mathrm{S}_{\mathrm{N}} 2$-mechanism (Scheme 3) which is however quite unlikely. In the case of 2 the product analyses proved ${ }^{9 a}$ that it gave 3-isopropylamino-1-butanol 10, with a direct $\mathrm{S}_{\mathrm{N}}$ 2-mechanism (Scheme 3). Obviously the secondary chloride reacts much slower since 1 reacts 80 -times faster than 2 with isopropyl amine. The first-order rate constant was $(45.0 \pm 1.3) \times 10^{-6} \mathrm{~s}^{-1}$ for 1 and $(0.55 \pm 0.02) \times 10^{-6} \mathrm{~s}^{-1}$ for 2 , the rate ratio being 80:1. When comparing the reactions of 3 and $\mathbf{4}$ with those of $\mathbf{1}$ and $\mathbf{2}$ with isopropyl amine $\mathbf{3}$ reacts ca 5 times slower than $\mathbf{1}$ whereas $\mathbf{4}$ reacts ca. 2 times faster than 2 . 


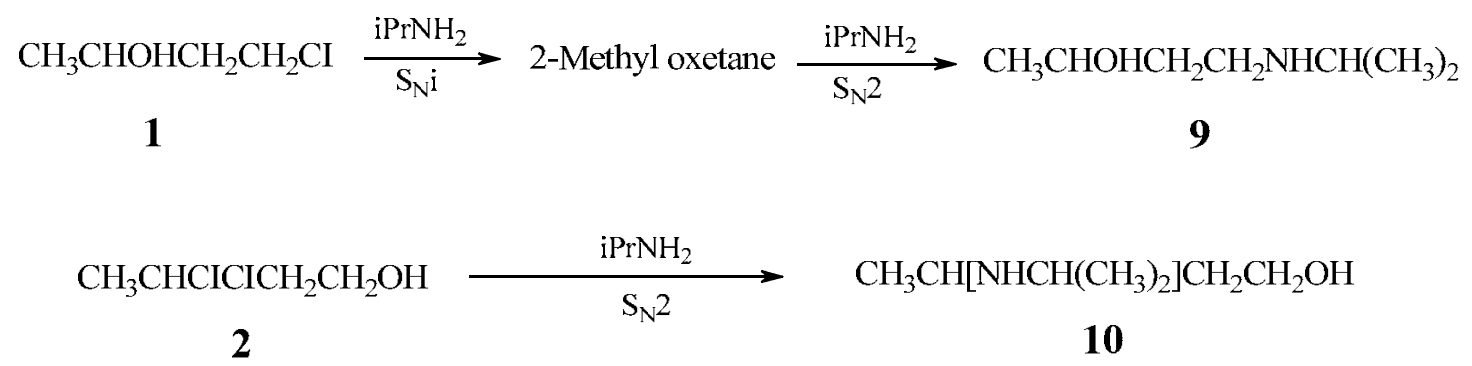

\section{Scheme 3}

\section{Conclusions}

4-Chloro-2-butanol 1 reacts with $\mathrm{NaOH}(\mathrm{aq})$ predominantly with $\mathrm{S}_{\mathrm{N}}$ i-mechanism whereas 3-chloro1-butanol 2 reacts mainly through 1,4-elimination (fragmentation, Scheme1) owing to their different I- and conformational effects. Correspondingly they also react with isopropyl amine giving different products, namely 4-isopropylamino-2-butanol 9 or 3-isopropylamino-1-butanol 10, respectively. 1Chloro-2-propanol 3 and 2-chloro-1-propanol 4 instead both react with isopropyl amine giving 1isopropylamino-2-propanol $\mathbf{8}$ and this reaction occurs in both cases via propylene oxide which gave the same product when reacted with isopropyl amine.

\section{Experimental Section}

General. 3-Chloro-1-butanol 2 was obtained in 79\% yield by reducing 3-chlorobutanoic acid by $\mathrm{LiAlH}_{4}$ as reported by Searles et al. ${ }^{10}$ Yield 79\%, b.p. $55-61{ }^{\circ} \mathrm{C} / 1.2 \mathrm{kPa}, \mathrm{n}_{\mathrm{D}}{ }^{20} 1.4410$ (Lit. ${ }^{11}$ bp. 74 ${ }^{\circ} \mathrm{C} / 2.1 \mathrm{kPa}, \mathrm{n}_{\mathrm{D}}{ }^{20}$ 1.4398). 4-Chloro-2-butanol 1 was prepared in $76 \%$ yield by reducing 4chlorobutanone by $\mathrm{LiAlH}_{4}$ as reported by Germain and Mirjolet. ${ }^{12}$ Yield $79 \%$, bp. $52-55{ }^{\circ} \mathrm{C} / 1.3$ $\mathrm{kPa}, \mathrm{n}_{\mathrm{D}}{ }^{20} 1.4415$ (Lit. ${ }^{13}$ bp. $67^{\circ} \mathrm{C} / 2.6 \mathrm{kPa}, \mathrm{n}_{\mathrm{D}}{ }^{20} 1.4408$ ). 4-Chlorobutanone 1 was obtained by saturating freshly distilled methyl vinyl ketone at $0{ }^{\circ} \mathrm{C}$ with dry $\mathrm{HCl}$ gas about $1 \mathrm{~h}$ as reported by Smith and Sprung. ${ }^{14}$ Yield $34 \%$, bp. $40-41^{\circ} \mathrm{C} / 1.3 \mathrm{kPa}\left(\right.$ Lit. $^{14}$ bp. $\left.38^{\circ} \mathrm{C} / 2 \mathrm{kPa}\right)$.

1-Chloro-2-propanol (3) was prepared from chloroacetone by reducing with $\mathrm{LiAlH}_{4}{ }^{15}$ After redistillation bp. $50-57{ }^{\circ} \mathrm{C} / 4.1 \mathrm{kPa}, \mathrm{n}_{\mathrm{D}}{ }^{20} 1.4365$ (Lit. ${ }^{15} \mathrm{bp} .64 .5{ }^{\circ} \mathrm{C}, \mathrm{n}_{\mathrm{D}}{ }^{25}$ 1.4366). 2-chloro-1propanol 4 was obtained by reducing $\alpha$-chloropropionyl chloride with $\mathrm{LiAlH}_{4}{ }^{16}$ After redistillation bp. $68-70{ }^{\circ} \mathrm{C} / 10 \mathrm{kPa}, \mathrm{n}_{\mathrm{D}}{ }^{20} 1,4365$ (Lit. ${ }^{16}$ bp. $38^{\circ} \mathrm{C} / 1.7 \mathrm{kPa}, \mathrm{n}_{\mathrm{D}}{ }^{25} 1.4362$ ).

1-chloro-3-(1-naphthoxy)-2-propanol 5, 1-isopropylamino-3-(1-naphthoxy)-2-propanol (propranolol, 6) and 1,2-epoxy-3-(1-naphthoxy)-2-propane 7 were kindly donated by Medipolar-Farmos Co. ${ }^{7}$

Reactions of (1) and (2) with isopropyl amine. $1 \mathrm{~g}(0.009 \mathrm{~mol})$ of 4-chloro-2-butanol 1 and $8.7 \mathrm{~g}$ $(0.147 \mathrm{~mol})$ of isopropyl amine were placed in two tightly closed screw cap test tubes and placed in 
an $80{ }^{\circ} \mathrm{C}$ oil bath for 5 days. The tubes were opened and the solutions filtered and the extra amine evaporated off. $10 \mathrm{ml}$ of water was added and the mixture made alkaline by adding $30 \% \mathrm{NaOH}(\mathrm{aq})$. Then the mixtures were extracted with $\mathrm{Et}_{2} \mathrm{O}$ and dried with $\mathrm{Na}_{2} \mathrm{SO}_{4}$. Based on chromatographic analysis $\mathbf{1}$ was completely converted to 4-isopropylamino-2-butanol $\mathbf{9}$, yield was practically quantitative (1.3 g, 99\%). ${ }^{1} \mathrm{H}$ NMR (ppm): $\left(\mathrm{CH}_{3}\right)_{2}$ 1.06; $\left(\mathrm{CH}_{3}\right)_{2} \mathrm{CH}$ and $\mathrm{CH}_{2} \mathrm{NH} 2.82, \mathrm{CHOH} 3.94$ and $\mathrm{CHOHCH}_{2}$ 1.55. ${ }^{13} \mathrm{C}$ NMR (ppm): $\left(\mathrm{CH}_{3}\right)_{2}$ and $\mathrm{CH}_{3}$ 22.7, 23.0 and 23.6 (not separately assigned), $\mathrm{CHOH} 69.9, \mathrm{CHOHCH}_{2} 37.6, \mathrm{CH}_{2} \mathrm{NH} 46.0$ and $\left(\mathrm{CH}_{3}\right)_{2} \mathrm{CH} 48.8$.

$2 \mathrm{~g}(0.018 \mathrm{~mol})$ of 3-chloro-1-butanol 2 and $17.4 \mathrm{~g}(0.294 \mathrm{~mol})$ of isopropyl amine were heated in an $80{ }^{\circ} \mathrm{C}$ oil bath. Thereafter one was proceeding as above. Based on gas chromatographic analysis 2 was completely converted in 3-isopropylamino-1-butanol 10, yield $1.8 \mathrm{~g}, 74 \%$. ${ }^{1} \mathrm{H}$ NMR (ppm): $\left(\mathrm{CH}_{3}\right)_{2}$ 1.05; $\left(\mathrm{CH}_{3}\right)_{2} \mathrm{CHNHCH} 2.89, \mathrm{CH}_{2} \mathrm{OH} 3.79$ and $\mathrm{HOCH}_{2} \mathrm{CH}_{2} 1.61 .{ }^{13} \mathrm{C} \mathrm{NMR}(\mathrm{ppm}):\left(\mathrm{CH}_{3}\right)_{2}$ and $\mathrm{CH}_{3}$ 21.0, 22.5 and 24.2 (not separately assigned), $\mathrm{CH}_{2} \mathrm{OH}$ 62.6, $\mathrm{HOCH}_{2} \mathrm{CH}_{2}$ 38.0, $\mathrm{CHNH} 51.5$ and $\left(\mathrm{CH}_{3}\right)_{2} \mathrm{CH} 45.5$.

Reactions of $(3,4)$ and propylene oxide with isopropyl amine. The reactions were carried out in 10-16-fold excess of isopropyl amine at $80-100{ }^{\circ} \mathrm{C}$ in an oil bath [e.g. $4.7 \mathrm{~g}(0.05 \mathrm{~mol})$ of 3 in $16-$ fold excess of isopropyl amine at $80{ }^{\circ} \mathrm{C}$ in a tightly closed test tube]. The mixtures were cooled to room temperature and filtered. Then 13-30 $\mathrm{ml}$ of water was added and the mixtures were hydrolysed by making them alkaline with $30 \% \mathrm{NaOH}$. The water solutions were extracted 3 times

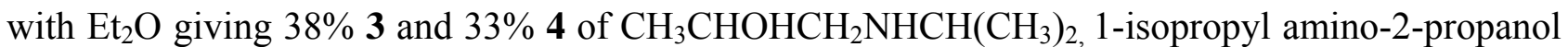
8. The reaction of propylene oxide with isopropyl amine was carried out with Krassusky's method ${ }^{17}$ and also this reaction gave 8 as the product. Yield $58 \%$, bp. $75-78{ }^{\circ} \mathrm{C} / 3.35 \mathrm{kPa}$. In all three cases 8 gave identical ${ }^{1} \mathrm{H}$ NMR spectra. ${ }^{13} \mathrm{C}$ NMR (ppm): $\mathrm{CH}_{3} 20.9,\left(\mathrm{CH}_{3}\right)_{2} 22.5, \mathrm{CHOH} 65.5, \mathrm{NHCH} 49.1$ and $\mathrm{CH}_{2} \mathrm{NH} 54.1$.

\section{Kinetic measurements}

A weighed amount of 4-chloro-2- 1 and 3-chloro-1-butanols 2 (+ internal standard n-amyl alcohol if used) and the base $(\mathrm{NaOH})$ solution were thermostated at least $1 \mathrm{~h}$ in the measuring temperature The base solution was poured quickly with mixing into the reaction vessel containing the substrate, the initial concentration of which was then obtained as $c_{0}$. Thereafter a sample was withdrawn immediately to determine gas chromatographically the peak area $\left(A_{0}\right)$ of the substrate and that $\left(\mathrm{A}_{\mathrm{o}}{ }^{\mathrm{IS}}\right)$ of the internal standard (if used).

The substrate concentrations of samples withdrawn at suitable intervals were obtained based on the gas chromatographic analyses as follows:

Method with internal standard: $c_{t}=\left(A_{t} / A_{t}^{I S}\right) /\left(A_{o} / A_{o}{ }^{I S}\right) c_{o}$

Method with external standard a constant amount injected: $c_{t}=\left(A_{t} / A_{o}\right) c_{o}$

$c_{t}$ is the substrate concentration $\left(\mathrm{mol} \mathrm{dm}{ }^{-3}\right)$ at time $t$ and $c_{o}$ that when $t=0$. $A_{t}$ is the peak area $(\mathrm{mVs})$ of the substrate at time $t$ and $A_{o}$ that at time $t=0 . A_{t}^{I S}$ is the peak area $(m V s)$ of the internal standard at time $\mathrm{t}$ and $\mathrm{A}_{\mathrm{o}}$ IS that at time $\mathrm{t}=0$. 
The gas chromatograph used for kinetic measurements was a Hewlett Packard 5700 equipped with a flame-ionization detector (FID). The column used was a 5\% Carbowax 20M-TPA/Chromosorb G AW-DMCS 80/100 mesh packed in a 1/8" steel column. The chromatographic conditions were:

(a) With internal standard: Injection chamber $200{ }^{\circ} \mathrm{C}$, detector $250{ }^{\circ} \mathrm{C}$, column oven 70 (4 min) $-190{ }^{\circ} \mathrm{C}(8 \mathrm{~min}) / 7^{\circ} \mathrm{C} / \mathrm{min}$, injection volume $10 \mu \mathrm{l}$ (Hamilton 710$)$.

(b) With external standard: Injection chamber $200{ }^{\circ} \mathrm{C}$, detector $250{ }^{\circ} \mathrm{C}$, column oven $110(2 \mathrm{~min})$ $-190{ }^{\circ} \mathrm{C}(8 \mathrm{~min}) / 7^{\circ} \mathrm{C} / \mathrm{min}$, injection volume $10 \pm 0.1 \mu \mathrm{l}$ (Hamilton $\left.\mathrm{CR} 700-20\right)$.

The peak areas and retention times were determined on a Varian 220-240D Chromatography computer system. The composition of the reaction mixtures was obtained from the equation:

$\mathrm{n}$

Contribution of component $\mathrm{i}(\mathrm{mol}-\mathrm{\%})=\mathrm{f}_{\mathrm{i}} \mathrm{A}_{\mathrm{i}} / \Sigma \mathrm{f}_{\mathrm{i}} \mathrm{A}_{\mathrm{i}}$ $\mathrm{i}=1$

where $f_{i}$ is the response factor for component $i$ and $A_{i}$ the peak area given by component $i$.

Table 5. Response factors determined for the initial reactants and reaction products

\begin{tabular}{cc}
\hline Compound & $\mathrm{f}$ \\
\hline Ethene & 35.7 \\
1-Propene & 23.8 \\
2-Methyloxetane & 23.3 \\
2-Buten-1-ol & 24.1 \\
Butane-1,3-diol & 24.1 \\
4-Chloro-2-butanol (1) & 24.1 \\
3-Chloro-1-butanol (2) & 24.9 \\
\hline
\end{tabular}

Alkenes were identified with a Varian 2800 Gas chromatograph equipped with two serially coupled $1 / 8$ " aluminium columns, of which the first (15 m) was packed with 15\% Sebaconitrile/Chromosorb P AW-MMCS 60/80 mesh and the second (3 m) with 10\% Squalane/Chromosorb P AW-DMCS $60 / 80$ mesh. At the column temperature of $45{ }^{\circ} \mathrm{C}$ the retention times of ethene $(670 \pm 5 \mathrm{~s})$ and propene $(880 \pm 5 \mathrm{~s})$ were strictly comparable to the retention times measured for hydrocarbon mixtures.

Second order rate constants $\mathrm{k}_{\mathrm{r}}$ for the reactions in $\mathrm{NaOH}(\mathrm{aq})$ were calculated from the equation

$$
\begin{aligned}
& \mathrm{y}=\mathrm{k}_{\mathrm{r}} \mathrm{t}+\mathrm{a} \text { where } \\
& \mathrm{y}=\left[1 /\left(\mathrm{c}_{\mathrm{o}}-\mathrm{b}\right)\right] \ln \left(\mathrm{bc}_{\mathrm{t}}\right) /\left[\left(\mathrm{c}_{\mathrm{o}}(\mathrm{b}-\mathrm{x})\right]\right.
\end{aligned}
$$

$\mathrm{t}=$ time, $\mathrm{a}=\mathrm{a}$ constant, $\mathrm{c}_{\mathrm{o}}$ initial substrate concentration $\left(\mathrm{mol} \mathrm{dm} \mathrm{m}^{-3}\right), \mathrm{b}$ initial $\mathrm{NaOH}$ concentration $\left(\mathrm{mol} \mathrm{dm}{ }^{-3}\right), x$ the amount of substrate $\left(\mathrm{mol} \mathrm{dm}^{-3}\right)$ reacted at time $\mathrm{t}$ (Table 4$)$. The base concentration appears to have no effect on $\mathrm{k}_{\mathrm{r}}$ (Table 4). The apparent fist-order rate constants for the reactions of 1-4 with isopropyl amine were easy to determine since the reactions were carried out in over 16fold excess of the latter. The prepared mixtures as stated above were divided in 10-15 tightly closed 
screw cap test tubes and placed in an oil bath at $80{ }^{\circ} \mathrm{C}$. The samples withdrawn at suitable intervals were analysed with a Perkin-Elmer F11 gas chromatograph equipped with flame ionization detector and two SE-30 columns. The column temperature was raised by $20{ }^{\circ} \mathrm{C} / \mathrm{min}$ from $50-175{ }^{\circ} \mathrm{C}$. The following rate $\left(\mathrm{k}_{\mathrm{t}}\right)$ equation was applied

$$
\mathrm{k}_{\mathrm{t}}=(1 / \mathrm{t}) \ln \left[\left(\mathrm{A}_{1}+\mathrm{A}_{2}\right) / \mathrm{A}_{1}\right]
$$

where $t=$ time, $A_{1}$ the peak area of the substrate and $A_{2}$ the peak area of the product.

\section{References}

1. (a) Bartók, M.,; Bozóki-Bartók, G.; Kóvacs, K. Acta Chim. Acad. Sci. Hung. 1970, 66, 115. (b) Bartók, M.; Láng-Lakos, K.; Bozóki-Bartók, G. Acta Chim. Acad. Sci. Hung. 1971, 70, 133. (c) Bartók, M.; Bozóki-Bartók, G.; Kóvacs, K. Acta Chim. Acad. Sci. Hung. 1972, 72, 297. (d) Bartók, M.; Bozóki-Bartók, G. Acta Chim. Acad. Sci. Hung. 1972, 72, 423. (e) Bartók, M.; Bozóki-Bartók, G. Acta Chim. Acad. Sci. Hung. 1972, 72, 433.

2. Searles, S., Jr.; Nickerson, R. G.; Witsiepe, W. K. J. Org. Chem. 1959, 24, 1839.

3. Richardson, W. H.; Golimo, C. M.; Wachs, R. H.; Yelvington, M. B. J. Org. Chem. 1971, 36, 943.

4. Lattes, A.; Verdier, A. Bull. Soc. Chim. France 1965, 2037.

5. Gaylord, N. G.; Crowdle, J. H.; Himmler, W. A.; Pepe, H. J. J. Am. Chem. Soc. 1954, 76, 59.

6. Forsberg, G. Acta Chem. Scand. 1954, 8, 135.

7. (a) Radulescu, D.; Muresqnu, P. L. Bull. Soc. Sci. Cluj. Roumanie 1932, 7, 128. (b) Heine, H. W.; Siegfried, J. J. Am. Chem. Soc. 1954, 76, 489. (c) Cowan, H. D.; McCabe, C. L.; Warner, J. C. J. Am. Chem. Soc. 1950, 72, 1194. (d) Harvey, K. J.; Riggs, N. V.; Stimson, V. R. J. Chem. Soc. 1955, 3267. (e) Aleksanyan, L. V.; Shvets, V. F. Arm. Khim. Zh. 1972, 25, 986. (f) Sippola, A. M. Sc. Report, University of Turku, 1981. (f) M-L. Kiuru, M. Sc. Report, University of Turku, 1984.

8. (a) Isotalo, R.; Lyytinen, M-R. Private Report, 1975. (b) K. Pihlaja, Private communication, 1975.

9. (a) Huusko, M-L. Upon the mechanism of the reaction between $\alpha$ - and $\beta$-chlorohydrines and amines and about the preparation of imines, MSc thesis (in Finnish), University of Turku, 1978.

(b) Hotokka, M. Upon the reactions of straight-chain and cyclic 1,2- and 1,3-halohydrines in acidic and alkaline conditions, MSc Thesis (in Finnish), University of Turku, 1978.

10. Sundaram, P.; Sharma, M. Bull Chem. Soc. Japan 1969, 42, 3141.

11. Searles, S. Jr.; Pollart, K. A.; Block, F. J. Am. Chem. Soc. 1957, 79, 952.

12. Germain, J.; Mirjolet, M. Bull. Soc. Pharm. Nancy 1966, 71, 26.

13. Sondheimer, F.; Woodward, R. B. J. Am. Chem. Soc. 1953, 75, 5438.

14. Smith, L. J.; Sprung, J. A. J. Am. Chem. Soc. 1943, 65, 1279. 
15. Fickett, W.; Garner, H. K.; Lucas, H. J. J. Am. Chem. Soc. 1951, 75, 5063.

16. Ballinges, P.; Long, F. A. J. Am. Chem. Soc. 1959, 81, 2347.

17. Patai, S. The Chemistry of Amino Group, Interscience Publishers, John Wiley \& Sons: London, $1968 ;$ p 351. 